Article

\title{
Shaping the Religiosity of Chinese University Students: Science Education and Political Indoctrination
}

\author{
Miao Li ${ }^{1}$, Yun Lu ${ }^{2, *(D)}$ and Fenggang Yang ${ }^{3}(\mathbb{D}$ \\ 1 Department of Sociology, Notre Dame University, Notre Dame, IN 46556, USA; mli13@nd.edu \\ 2 Department of Sociology and Social Work, Sun Yat-sen University, Guangzhou 510275, China \\ 3 Department of Sociology, Purdue University, West Lafayette, IN 47907, USA; fyang@purdue.edu \\ * Correspondence: luyun7@mail.sysu.edu.cn
}

Received: 10 September 2018; Accepted: 4 October 2018; Published: 11 October 2018

\begin{abstract}
Our study examined the respective relationships between two components of higher education in mainland China-science education and political indoctrination-and the religiosity of university students. Using a cross-sectional, representative sample of about 1700 college students in Beijing, we found first that students studying natural/applied sciences were less likely to perceive Protestantism, Catholicism, and Islam as plausible and less likely to have supernatural belief, relative to students in humanities/social sciences. In addition, the more students positively evaluated the political education courses-which indicates students' acceptance of political indoctrination-the less likely they reported Protestantism and Catholicism as being plausible. Nevertheless, neither science education nor political indoctrination was associated with the perceived plausibility of Buddhism and Daoism or the worshipping behavior of students. We discuss the implications of these findings in light of the secularization debate and the research on education, religion, and state atheism.
\end{abstract}

Keywords: higher education; religiosity; science education; political indoctrination; atheism

\section{Introduction}

Influences of higher education on religiosity have attracted much scholarly attention. While many studies have portrayed universities as unfriendly places for religion (e.g., Caplovitz 1977; Hunter 1983), others have documented stable rates of religious commitment of college students (e.g., Hill 2009, 2011; Mayrl and Uecker 2011; McFarland et al. 2011; Reimer 2010). Most studies on the topic have been done in the United States, where religious freedom is protected. Nevertheless, it is unclear how higher education influences students' religiosity in places where religious freedom is restricted and where the state-enforced secularization curriculum tries to systematically undermine the plausibility of religion.

Governments in many countries have practiced or are practicing state atheism, a secularization movement with a goal of eradicating religion. These governments often take a series of radical measures to secularize higher education, such as forbidding religious preaching on campus and enforcing anti-religious curricula. So far, only a few studies have examined the relationship between higher education and religion in these antireligious settings, and the findings have been mixed (Sacerdote and Glaeser 2001; Schwadel 2015; Wang and Uecker 2017; Xie et al. 2017). These mixed findings may be due to the fact that the studies generally compared religiosity between populations of different education levels, an approach that fails to untangle the various components of higher education and so does not shed much light on the mechanisms through which higher education shapes students' religiosity. Scholars have identified multiple components of modern higher education that may undermine students' religiosity, with natural science education often invoked as the most prominent one (Halman 
and Draulans 2006; Johnson 1997; Schwadel 2011). In countries with state-enforced secularization, however, there are additional components to be considered, most notably the mandatory political indoctrination of students with atheism and nationalism.

The purpose of the present study is to examine the extent to which two important components of higher education in China-science education and political indoctrination-influence students' religiosity. Through focusing on the religiosity of college students, this study helps shed light on the influences of higher education on the overall religious landscape. In China, there exists a religion-science-conflict discourse in which religions have been labelled with superstition and backwardness, while science has been labelled with modernity and progressiveness and has been embedded in science education. In addition, the Communist Party of China (CPC, hereafter) is indoctrinating university students with an atheist ideology through political education programs. Therefore, we hypothesized that science education and political indoctrination would impair religiosity among Chinese college students. We also argue that the negative influences of this political indoctrination on religiosity may be particularly pronounced for Christianity, a religion that has been historically linked with Western colonialism and has a strong mobilization capacity. The current study is based on a representative sample of university students in Beijing, the capital city of China, which has the highest concentration of higher education institutions in the country. Findings from this study will advance our understanding of the relationship between higher education and religion in countries with state-enforced secularization by unpacking the "black box" of the mechanisms via which higher education influences religiosity in an antireligious setting.

\section{Science Education and Religiosity}

A popular narrative in social sciences predicts that exposure to science and its epistemological approach to knowledge will undermine religion (e.g., Comte 2015; Ruiter and van Tubergen 2009; Weber 1993). Scholars following this education-religion-conflict narrative argue that science and religion use different methods for making truth claims about the natural world. Embracing the epistemological view of natural and applied sciences therefore is believed to impair the religious faith and activity of students (Evans and Evans 2008). One approach that past works in the U.S. have taken to examine this science-religion-conflict argument is to compare the religiosity between scholars and college students from different academic backgrounds. However, the evidence in this approach is mixed. For example, one study found that students in natural science/engineering tended to favor science over religion compared to those in social sciences/humanities (Scheitle 2011). In contrast, other studies contended that scholars in social sciences/humanities were not less religious than natural scientists (Gross and Simmons 2009; Stark and Finke 2000), or they found that there were no significant differences in the view of the religion-science relationship between the two groups of scholars (Ecklund and Park 2009). There are some potential explanations for why science education may not weaken religiosity among students. First, people may perceive science and religion as being separate instead of as being alternatives. It may be that the subject matter and methods of natural science do not directly examine religion itself and also that many individuals still understand their daily life through a religious lens (Lehman and Shriver 1968; O'Brien and Noy 2015). Second, vibrant ministry work on campuses provides opportunities for students to engage in various forms of religious worship, which may offset the effect of natural science education (Cherry et al. 2001; Uecker et al. 2007).

Although the findings on the science education-religion link are mixed in the U.S., we expected an undermining effect of science education on religiosity in China. Different from the popular view in the U.S. that science and religion belong to separate areas, the science-religion-conflict discourse is well integrated into the Chinese education system. In the early 20th century in China, progressive intellectuals launched the May Fourth Movement (1919) as well as the companion New Culture Movement in the mid-1910s and 1920s as an endeavor for cultural renewal. Two signature slogans of these movements were "Mr. De (Mr. Democracy)" and "Mr. Sai (Mr. Science)". In the "Mr. Science" discourse, science, especially natural and applied sciences, was portrayed as knowledge that was 
rational and progressive and that was the promise for a modern and prosperous nation, while religion was connected to ignorance, backwardness, superstition and a barrier to modernity and development. These intellectuals argued that national rejuvenation was impossible until religions (or superstitious beliefs) were replaced by modern sciences ${ }^{1}$. Such intellectual discourse had a profound influence over subsequent social thought in the country. According to a recent survey about the spiritual life of Chinese residents, about 67 per cent of respondents agreed that people should only believe in science and not in any religion. The influence of the religion-science-conflict discourse, through the promotion of official propaganda, is particularly strong in the contemporary higher education context (Ji 2015). Based on this reasoning, we hypothesized that natural/applied science education would be negatively associated with religiosity among university students in China (H1).

Further, the other explanatory mechanism mentioned above, that dynamic campus ministries help preserve the religious plausibility in spite of the science education, may be less effective in the Chinese context. Although some religious activists have been conducting underground missionary work on campus, the Chinese government has prohibited proselytization activities by religious organizations (even legally sanctioned religious organizations) on campuses. Therefore, these proselytization activities in China's universities may be less vibrant and effective than their counterparts in the U.S. and thus might not be able to offset the secularizing effect of the science education.

\section{The CPC's Political Indoctrination}

Mandatory political indoctrination with anti-religious content is a unique phenomenon in socialist higher education. The CPC has systematically incorporated political indoctrination programs into the higher education system since it assumed national power in the late 1940s. The purpose of political indoctrination is to propagate the Party's ideology and guiding socio-economic principles, as well as to prepare the highly educated to be politically subservient in the future. The content of the political indoctrination is composed of atheism, authoritarianism, and nationalism. The political indoctrination is implemented via two primary mechanisms in colleges: (1) mandatory political education courses and (2) student Party member recruitment. The former targets are all students, while the latter are more focused on elite students.

Mandatory political education courses are built into the higher education curricula. All university students are required to take a series of political education courses in which the Party's ideology is systematically taught ${ }^{2}$ Of course, students vary in their responses to these political indoctrination programs. Some passively resist, some grow aloof or cynical, while others consider the programs useful and necessary. These different responses serve as a good indicator of the students' intellectual stance towards the Party's ideological teachings. Therefore, we hypothesized that students with a more positive attitude towards the political education courses would be less religious $(\mathrm{H} 2)$.

Meanwhile, universities are a primary recruiting ground of the CPC. University CPC recruitment is a highly selective and stringent process $^{3}$. It takes at least two years to attain full membership, during which time applicants must attend a series of special training programs, report to the local CPC branch, take exams, and undergo a probation period. After being recruited, the student members must regularly participate in Party activities to continue their political studies. Given the selection process and dramatically different levels of exposure to the Party's ideology between the CPC students and

1 Cai Yuanpei, then-president of Peking University and a prominent leader of the New Culture Movement, publicly denounced religion as being outdated and obsolete. He instead preached that religion should be replaced by aesthetic education. Other leaders, such as Hu Shi (a student of John Dewey), took a similar secularist stance and decried religion as being irrelevant in the modern world. Chen Duxiu, another well-known intellectual at that time, argued that to avoid being colonized, traditional Chinese culture must be replaced with science and democracy.

2 The mandatory political education courses are currently 马克思主义基本原理 (Basic Principles of Marxism), 毛泽东思想和 中国特色社会主义理论体系概论 (Mao Zedong Thought and the Theory of Socialism with Chinese Characteristics), 中国近 现代史纲要 (Modern History of China), 思想道德修养与法律基础 (Moral and Legal Education), and 形势与政策 (National Condition and Policy). For more detailed information on these courses, see http:/ / www.sxz.edu.cn.

3 The recruitment is a highly selective and stringent process. It was reported that the CPC's acceptance rate in 2014 was on a par with the Ivy League-2 million applicants were accepted from a pool of 22 million (McMorrow 2015). 
the non-CPC students, a comparison of their religious plausibility opinions provides an additional tool for testing the influence of political indoctrination. We hypothesized that students who are CPC members would be less religious than non-CPC students (H3).

\section{Anti-Christianity Religious Policy of the CPC}

Political education courses may have a particular undermining effect on students' perceptions of Christianity, because the CPC's authoritarian and nationalistic teachings often single out Christianity as a potential threat for several reasons. First, Christianity has been historically connected with imperialism and is still suspected by the party of being a tool for infiltration by the West. Second, the CPC's vigilance towards Christianity has escalated via a momentum-gaining intellectual discourse-inspired by the Solidarity movement in Poland and other pro-democratic movements- that associates Christianity with liberal democracy (e.g., Huntington 1993). Last—but not less crucial—the government is very concerned with the mobilizational potential of religious groups. The power of religious groups in mobilizing massive protest movements was an important catalyst for the collapse of some former East European communist regimes. Recently, leaders of some independent churches in China have been active in social movements that aim to achieve political change (Vala 2012). The CPC's hostile attitude towards Christianity is illustrated by the government campaign to remove crosses from church buildings that took place from 2014 to 2015 in Zhejiang Province, the heartland of Chinese Christianity. In fact, such a massive antireligious campaign has rarely happened to other religions since the late 1970s. When it comes to the political indoctrination in the higher education context, top Party leaders in charge of propaganda and ideology have expressed concern about the growing influence of Christianity on campuses and have urged rank-and-file cadres to contain it in colleges (Ifeng 2015; Xinhuanet 2017).

In contrast, other religions are portrayed somewhat positively in CPC's propaganda. The authorities view Buddhism and Daoism as spiritual cures for the social anomie, which is a byproduct of social transformation, as well as forces to counterbalance the rapid growth of Christianity. In particular, the party uses Buddhism as a channel to boost China's "soft power" globally (Johnson 2017a, 2017b, 2018; Laliberté 2011). As for Islam, the authorities do not explicitly frame this religion per se as a disruptive force of national unity, though the party-state has placed serious restrictions on Islamic activities in the northwestern provinces. For example, about the violent incidents related to some Muslims, the official media emphasized that it was a handful of terrorists and separatists who were to blame, while the majority of Chinese Muslims were patriotic and peaceful (People's Daily 2014, 2016). The discriminatory religious policy of the CPC may be embodied in the content of the political education courses. It is possible that students who find the political education courses helpful choose to avoid Protestantism and Catholicism, two major types of Christianity in China. Therefore, the negative association between the positive attitudes towards political education courses and the perceived plausibility of Protestantism and Catholicism were stronger than for other religions (H4).

\section{Data and Methods}

\subsection{Data}

The analysis was based on data from the Beijing University Students Religious Attitudes Survey, which is a cross-sectional study of a representative sample of university undergraduate and graduate students enrolled between 2007 and 2010 in universities in Beijing. The survey is a part of the Chinese Spirituality and Society Program, based at the Center on Religion and Chinese Society at Purdue University and funded by the John Templeton Foundation ${ }^{4}$. The primary objective of the study was to collect data about university students' attitudes toward religion, involvement in religious activity,

4 For more information, see https://www.purdue.edu/crcs/projects/cssp/. 
and religious knowledge in order to understand the sociocultural factors influencing college students' religious cognitions, knowledge, and practices. The survey was conducted in April-June 2011.

The study follows a multistage stratified probability design. The primary sampling frame covers all public universities $(\mathrm{N}=55)$ in Beijing. From this frame was selected a stratified sample of 13 universities with probability proportional to size $\mathrm{e}^{5}$. Universities were stratified by National Department of Education ranking ("985" or "211" project universities, other first-tier universities, and second-tier universities) ${ }^{6}$, school type (comprehensive universities, social science and humanities, science and engineering, medical universities, fine arts, and sports universities), and ethnic composition (ethnic minority universities and regular universities). Our sample of universities reflects the diversity of university ranking, school types, and ethnic composition, thus representing not only the universities located in Beijing but also to some degree the higher education sector in China. The secondary sampling frame covers all student residential units in each university (in China, the overwhelming majority of students live in residential units assigned by the university). One student was randomly selected for interviewing in each randomly selected room from the sampled residential unit. In total, 1876 university students were successfully interviewed (response rate $=93.8 \%$ ). After a list-wise deletion of observations that had missing data, the final analytical sample sizes varied across models with different dependent variables (ranging from 1669 to 1736).

Here we first present the descriptive statistics (Table 1). Then, we present the fitted logistic regression models for the perceived plausibility of the five major religions and for religious behavior among college students, and the estimated linear regression models for a supernatural belief score. Estimated coefficients and associated standard errors for all predicting variables are presented (Table 2). All analyses were weighted by the sampling weights to account for the complex multistage cluster sampling design. We used the listwise deletion to address the missing values and so that the regression results presented were based on observations with available data on all variables included in the models.

Table 1. Descriptive Statistics.

\begin{tabular}{ccccc}
\hline & Mean & Standard Deviation & Min & Max \\
\hline Outcome Variables & & & & \\
Buddhism plausibility & 0.378 & 0.485 & 0 & 1 \\
Daoism plausibility & 0.213 & 0.410 & 0 & 1 \\
Protestantism plausibility & 0.188 & 0.390 & 0 & 1 \\
Catholicism plausibility & 0.092 & 0.289 & 0 & 1 \\
Islam plausibility & 0.076 & 0.265 & 0 & 1 \\
Worshipping behavior & 0.729 & 0.444 & 0 & 1 \\
Supernatural Belief & 0.000 & 1.000 & -2.552 & 3.071 \\
Independent Variables & & & \\
Science/engineering/medical area of study & 0.440 & 0.497 & 0 & 1 \\
Evaluation of political education courses & 2.500 & 1.029 & 1 & 5 \\
CPC membership & 0.283 & 0.451 & 0 & 1 \\
\hline
\end{tabular}

5 The 13 universities are Peking University, Tsinghua University, Renmin University of China, Minzu University of China, China University of Political Science and Law, China University of Geoscience, Beijing University of Post and Telecommunication, Beijing University of Chemical Technology, Capital Medical University, Beijing Film Academy, Beijing University of Civil Engineering and Architecture, Capital Normal University, and University of International Relations.

6 Universities in mainland China could be divided into two broad types: first tier (一本) and second tier (二本). Among the universities classified as part of the first tier, some have been selected for the so-called "985" project or "211" project, and these are regarded as elite higher education institutions. In 2017, the "985" and " 211 " projects were replaced with the “Double First-Rate" project (双一流). 
Table 1. Cont.

\begin{tabular}{ccccc}
\hline & Mean & Standard Deviation & Min & Max \\
\hline Covariates & & & & \\
Age & 22.428 & 2.904 & 12 & 41 \\
Women & 0.471 & 0.499 & 0 & 1 \\
Sense of control & 6.771 & 1.630 & 1 & 10 \\
Urban origin & 0.654 & 0.476 & 0 & 1 \\
Have contacted a Buddhist missionary & 0.073 & 0.260 & 0 & 1 \\
Have contacted a Daoist missionary & 0.008 & 0.089 & 0 & 1 \\
Have contacted a Protestant missionary & 0.551 & 0.498 & 0 & 1 \\
Have contacted a Catholic missionary & 0.079 & 0.270 & 0 & 1 \\
Have contacted an Islamist missionary & 0.049 & 0.216 & 0 & 1 \\
Have contacted missionary of any religion & 0.661 & 0.473 & 0 & 1 \\
Father's occupation & & & & \\
Managerial/Professional & 0.422 & 0.494 & 0 & 1 \\
Administrative staff & 0.098 & 0.297 & 0 & 1 \\
Manual labor & 0.420 & 0.494 & 0 & 1 \\
Other & 0.060 & 0.238 & 0 & 1 \\
\hline
\end{tabular}

Source: Beijing College Students' Religious Attitudes Survey 2011.

Table 2. Regression Model Coefficients for the Perceived Plausibility of Five Religions, Religious Behavior, and Supernatural Belief of College Students in Beijing.

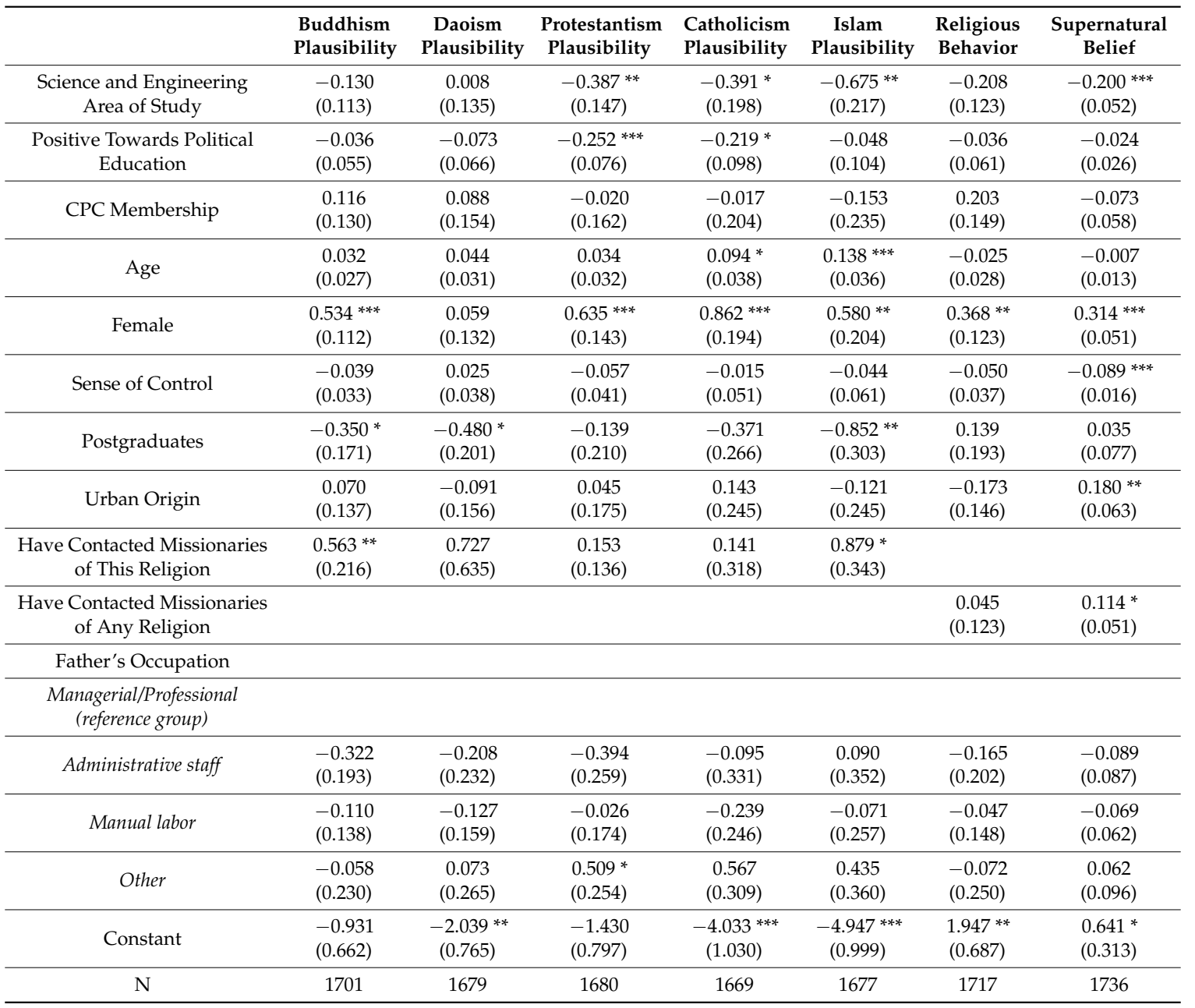

Standard errors in parentheses. ${ }^{*} p<0.05,{ }^{* *} p<0.01,{ }^{* * *} p<0.001$. Source: Beijing College Students' Religious Attitudes Survey 2011. 


\subsection{Dependent Variables}

The perceived plausibility of the five major religions-Protestantism, Catholicism, Buddhism, Daoism, and Islam - constitute the five dependent variables in this analysis. Each dependent variable was measured with a single survey question: "Regardless of whether you go to church or temple, do you believe in [the religion]?" Original choices provided were: "do not believe", "do not believe very much", "somewhat believe", and "believe". Due to the gradations of the answers and the ambiguity of religious identity in Chinese society, we think that these questions actually measure respondents' perceived plausibility of a specific religion, rather than actual religious belief or identity. To validate the claim, we found that when students were later asked about their religious identity, around 72 per cent of those who chose "somewhat believe" or "believe" Buddhism reported having no religious identity. Additionally, for the other religions, such figures remained rather stable at around 70 per cent. To take into account the potential qualitative differences between "believe" and "not believe", we recoded these variables dichotomously, with 1 representing "somewhat believe or believe" and 0 otherwise.

Religious behavior was measured by the question, "In the past year, did you worship divinities in any of the following places: religious site; cemetery, or ancestry hall; home; work place; or other place." We coded this as a dummy variable in which students who worshipped in any one of these places were 1 and otherwise 0 . About 70 per cent of the students reported having worshipping behavior.

We constructed a supernatural belief factor score from the five items through principlecomponent analysis. Scholars of religion in the Chinese context have pointed out that although many Chinese do not hold an exclusive and clear religious identity, they may believe in the existence of ghosts, gods, or demons and follow spiritual or superstitious practices such as fortune-telling and Fengshui. To measure students' supernatural beliefs, we used five items from a question in the survey, "What is your opinion on these arguments? (1) There is a supernatural force; (2) Humans have a soul; (3) Fortune-telling and Fengshui are effective; (4) Astrology is important for one's life; and (5) Everything is determined by fate." The original five choices ranged from "strongly agree" to "strongly disagree". The Cronbach's alpha of these five items was 0.751 . Factor analysis revealed one factor that we referred to as a belief in supernatural forces. The eigenvalue of the supernatural belief factor was more than 50 per cent of the total, and the factor loading of the five items was between 0.7379 and 0.6355 .

\subsection{Key Independent Variables}

Science education was measured as a dummy variable that took the value of 1 if the student was studying natural sciences/engineering/medical sciences and 0 otherwise. In the "otherwise" category, more than 98 per cent of the students were studying Social Sciences or Humanities and the rest were studying Fine Arts or Sports.

We examined two independent variables related to political indoctrination: CPC membership and attitude towards political education courses. CPC membership was measured with the question, "What is your political affiliation?" ( $1=$ formal or probationary member; $0=$ otherwise). Students were asked how much they agreed with the statement that "political education courses are beneficial". Responses were coded along a 5-point scale ranging from "absolutely do not agree" to "absolutely agree" and were used to measure students' receptiveness toward political education.

\subsection{Control Variables}

We controlled for some basic characteristics of the students: gender $($ woman $=1$, $\operatorname{man}=0$ ), age (measured in years), urban-rural origin (urban $=1$, rural $=0$ ), and level of program enrolled in (postgraduate $=1$, undergraduate $=0$ ). We also controlled for the sense of control over one's own life based on the question, "How much do you think you can control your own life?" Responses were coded on a 10-point scale ranging from 1 (no control at all) to 10 (complete control). Father's occupation 
was used as a proxy for students' socio-economic status, which consisted of four occupational categories: managerial or professional (reference group), administrative staff, manual labor, and other. In addition, we constructed a dichotomous variable to indicate whether students had contacted religious missionaries or not (have contacted $=1$, have not contacted $=0$ ).

\section{Results}

The descriptive statistics are presented in Table 1. The respondents who viewed Buddhism as plausible were more than a third of the sample, one percentage higher than for any other religion. Buddhism appeared more authentic to university students than the other religions. For Daoism and Protestantism, the proportion of the respondents who reported them as plausible was about 21 and 19 per cent, respectively. The numbers of students with a positive perception of Daoism and Protestantism were close. The percentages of Catholicism and Islam were the lowest among the five religions, about 9 and 8 per cent, respectively. About 73 per cent of the students reported having worshipping behavior. CPC members were 28 per cent of all respondents. Students studying science/engineering/medicine comprised 44 per cent of the sample.

Table 2 reports the estimated coefficients and associated standard error for the perceived plausibility of the five religions, religious behavior, and belief in supernatural forces. We first looked at the results for those studying natural sciences/engineering. There were significant differences between students who were studying natural sciences/engineering and those who were studying other disciplines in terms of the plausibility of Protestantism, of Catholicism, and of Islam. Students with a sciences/engineering/medical background were 32.1 per cent (1-exp[-0.387]), 32.4 per cent (1-exp[-0.391]), and 49.1 per cent (1-exp[-0.675]) less likely than those studying in other areas to perceive Protestantism, Catholicism, and Islam as plausible, respectively. However, regarding the plausibility of Buddhism and Daoism, there were no significant differences between the two groups of students.

As for religious behavior, this did not relate to those studying natural sciences/engineering. There were no significant differences among students from different academic backgrounds regarding the likelihood of worshipping divinities. However, in terms of supernatural belief, we found that students with a science/engineering background were 18.1 per cent (1-exp[-0.200]) less likely to support this belief than those studying in other areas. Thus, we found some support for Hypothesis 1, which posited that students studying natural sciences/engineering were less religious than other students. Although science education was related to lower levels of perceived plausibility of Protestantism, Catholicism, and Islam and to supernatural belief, it was not significantly associated with perception of Buddhism and Daoism or with worshipping behavior.

Here, we discuss the findings on political indoctrination. The first measurement of political indoctrination was students' attitudes towards political education. Evaluation of the university political education program was significantly related to the perceived plausibility of Protestantism and Catholicism. Students who spoke highly of the political education courses were 22.3 per cent (1-exp[-0.252]) and 19.7 per cent (1-exp[-0.219]) less likely to report Protestantism and Catholicism, respectively, as being plausible. On the other hand, evaluation of political education programs was not associated with the perceived plausibility of Buddhism, Daoism, or Islam. Moreover, we found that evaluation of political education was not related to religious behavior or supernatural belief. Therefore, a positive attitude towards political education was only related to the perceived plausibility of Protestantism and Catholicism, while not being associated with other indicators of students' religiosity. These findings do not support Hypothesis 2, which posits a negative association between the evaluation of political education courses and all religiosity indicators of college students. Instead, we found that Hypothesis 4, which expects that the political education course mainly affects the perceived plausibility of Protestantism and Catholicism, was supported by the statistical evidence.

As the second measurement of political indoctrination, CPC membership was found not to be related to any indicator of students' religiosity. It seems that students who were CPC members were not 
less religious than others who did not obtain CPC membership. These findings were not supportive of Hypothesis 3, which posited a negative association between CPC membership and students' religiosity.

Among the control variables, age was not positively related to the indicators of religiosity except for the perceived plausibility of Catholicism and Islam. Female students were more likely to have a positive perception of the plausibility of all the religions except for Daoism and were more likely to worship divinities and to support supernatural belief. Postgraduate students were less likely to consider Buddhism, Daoism, and Islam as being plausible than were undergraduates, but there were no significant differences between postgraduates and undergraduates on other religious indicators. In addition, the only difference between students from urban and rural backgrounds was that students from cities were more likely to support supernatural belief. The father's occupation, indicating a student's social and economic status, was not found to be consistently associated with a student's religiosity. Additionally, there was no significant association between the sense of control over one's life and any indicators of religiosity except for supernatural belief.

\section{Conclusions and Discussion}

This study examined how two components of higher education in China-science education and political indoctrination-influenced the religiosity of college students, using a cross-sectional analytic sample of about 1700 college students in Beijing. We found that, first, students studying natural sciences/engineering were less likely than those studying in other areas to perceive Protestantism, Catholicism, and Islam as plausible and to have a supernatural belief. This partially supports our hypothesis that science education would be negatively associated with students' religiosity.

Why did science education not weaken the perceived plausibility of Buddhism and Daoism? This may be because Buddhism and Daoism are widely perceived to be part of popular culture. Today, many Buddhist and Daoist activities are still carried out in the name of traditional culture (Yang 2006). It is very possible that Buddhism and Daoism are treated by college students as a combination of philosophical thoughts, ethical teachings, and health practices. Since they are perceived as part of traditional culture, therefore, the two religions may not be perceived of as in a head-on conflict with science by students studying science.

Similarly, the insignificant association between science education and religious behavior may be due to the fact that some worshipping activities are viewed as cultural, touristic, or habitual. For example, quite a few religious sites in mainland China, especially Buddhist and Daoist temples, have recently been reconstructed as tourist sites. When Chinese tourists visit these temples, it is a common practice for them to burn incense or to bow to the gods. Additionally, visiting ancestors' tombs during the Qingming Festival, in which offering sacrifices and bowing are indispensable elements, is a regular family activity for many Chinese. People usually conduct this ritualistic worshipping activity for family cohesion and for mourning departed relatives, without necessarily believing in the existence of the ancestors' souls.

Another finding of the present study is that the positive evaluation of political education courses was related to low levels of the perceived plausibility of Protestantism and Catholicism. However, the evaluation of political education courses was not related to how students perceived Buddhism, Daoism, or Islam, or to their religious behavior and supernatural belief. It seems that the Party's political indoctrination particularly threatens the Christian faith. As we articulated in the hypothesis-developing section, due to Christianity's international connections and strong mobilization capacity, the leadership of the CPC is alert to the growth of Christianity in China and are taking measures to contain its burgeoning influence in colleges. Therefore, the content of the political education courses may be particularly hostile to Protestantism and Catholicism.

CPC's membership, which is the other measurement of political indoctrination, was found not to be related to the perceived plausibility of religions, religious behavior, or supernatural belief. This may be because many students join CPC for material interests. CPC membership is often a prerequisite for getting a job at a public institution or a state-owned enterprise. In many cases, it is the potential 
material interests, rather than ideological passion, that motivate students to join the party. These student members motivated by material interests may in fact be indifferent to the official propaganda. This finding echoes one study that found that many CPC members were engaged in some kind of religious activity (Yang 2015).

Our findings have rich implications for the literature. So far, only a few studies have examined the association between education and religion in former/current socialist countries. The results from these studies are confusing: One study found that the negative effect of higher education on religion was stronger in communist countries (Sacerdote and Glaeser 2001); Another showed that the secularizing effect of higher education did not vary between communist and non-communist countries (Schwadel 2015); Other studies found that higher education was positively related to religiosity in China (Wang and Uecker 2017; Xie et al. 2017). These studies often used a single indicator-that is, the educational level—to represent the influences of higher education. Our research improves on these studies in two ways and helps address the inconsistency problem in these past works. First, we distinguished between science education and political education courses. The findings showed that science education and political education courses had different influences on students' religiosity. Second, we accounted for different religiosity dimensions, respectively. We found that science education and political education courses were negatively related to the perceived plausibility of Protestantism and Catholicism and to supernatural belief. In other words, our research suggests that higher education in China does change students' religiosity, though the effects of higher education vary among the types of education and among the religious dimensions.

Moreover, our findings provide more nuances for the debate on the secularizing effects of higher education. Most research that has debated whether higher education reduces religiosity has been conducted in the U.S. or Europe, where the dominant religion, either Protestantism or Catholicism, is highly institutionalized and well separated from other social areas (e.g., Hill 2009, 2011; Mayrl and Uecker 2011; McFarland et al. 2011; Reimer 2010; Schwadel 2011). However, in the present research, science education was found not to result in a lower plausibility level for Buddhism and Daoism. As we explained earlier, it may be that the values, practices, and beliefs of Buddhism and Daoism are merged in popular culture. In contrast, the acquisition of scientific knowledge was a weakening factor in the religious plausibility of Protestantism and Catholicism, a finding in-line with previous research in the U.S. that argued for the secularizing effect of science education. Therefore, our findings suggest that, in China, the effects of science education in this regard differ between "Western" religions and "traditional" religions.

There are several limitations in this study. The sample only covered college students in Beijing, the capital of China, where the political indoctrination programs might be more seriously implemented and so might have a stronger influence than in other cities with a looser political environment. If a national sample becomes available in the future, it is necessary to re-examine the findings from this study on a nationwide scale. In addition, this study is based on cross-sectional survey data with the inherent disadvantage of causal inference. The model results show statistical correlations instead of a causal relationship. It is possible that students who are inclined towards religion/supernatural belief will self-select into humanities/social sciences disciplines. Similarly, some students who agree with scientism are more likely to choose to major in natural sciences/engineering. Thus, the negative association between science education and some religious dimensions may be partly due to this selection mechanism. Further research could take into account this selection processes when longitudinal data on education and religion in China become available.

Our study contributes to the knowledge on education and religion, even though some limitations remain. First, we found that science education and political indoctrination had different influences on students' religiosity. This finding helped open the "black box" of how higher education influences religiosity in an antireligious context. Second, the findings in this study suggest that science education in college has a limited effect on the perceived plausibility of religions whose values and practices have become part of popular culture. This provides more nuances to the secularization debate around 
higher education and religion. Third, our findings show that students who agreed with the content of political education courses reported lower levels of perceived religious plausibility of Christianity. This finding implies a discriminatory religious policy on the part of the CPC towards certain religions.

Author Contributions: Conceptualization, M.L. and Y.L.; methodology, M.L.; formal analysis, M.L. and Y.L.; investigation, F.Y.; resources, F.Y.; data curation, M.L.; writing-original draft preparation, M.L. and Y.L.; writing-review and editing, M.L., Y.L. and F.Y.

Funding: This research received no external funding.

Conflicts of Interest: The authors declare no conflict of interest.

\section{References}

Caplovitz, David. 1977. Religious Drop Outs: Apostasy among College Graduates. Newcastle upon Tyne: SAGE.

Cherry, Conrad, Betty A. DeBerg, and Amanda Porterfield. 2001. Religion on Campus: What Religion Really Means to Today's Undergraduates. Chapel Hill: University of North Carolina Press.

Comte, Auguste. 2015. A General View of Positivism. Whitefish: Kessinger Publishing. First published 1865.

Ecklund, Elaine Howard, and Jerry Z. Park. 2009. Conflict between Religion and Science among Academic Scientists? Journal for the Scientific Study of Religion 48: 276-92. [CrossRef]

Evans, John H., and Michael S. Evans. 2008. Religion and Science: Beyond the Epistemological Conflict Narrative. Annual Review of Sociology 34: 87-105. [CrossRef]

Gross, Neil, and Solon Simmons. 2009. The Religiosity of American College and University Professors. Sociology of Religion 70: 101-29. [CrossRef]

Halman, Loek, and Veerle Draulans. 2006. How Secular Is Europe? The British Journal of Sociology 57: 263-88. [CrossRef] [PubMed]

Hill, Jonathan P. 2009. Higher Education as Moral Community: Institutional Influences on Religious Participation during College. Journal for the Scientific Study of Religion 48: 515-34. [CrossRef]

Hill, Jonathan P. 2011. Faith and Understanding: Specifying the Impact of Higher Education on Religious Belief. Journal for the Scientific Study of Religion 50: 533-51. [CrossRef]

Hunter, James Davison. 1983. American Evangelicalism: Conservative Religion and the Quandary of Modernity. New Brunswick: Rutgers University Press.

Huntington, Samuel P. 1993. The Third Wave: Democratization in the Late Twentieth Century. Norman: University of Oklahoma Press.

Ifeng. 2015. Diyu Liyong Zongjiao dui Gaoxiao Jinxing Shentou He Fangfan Xiaoyuan Chuanjiao (Resisting Religious Infiltration in Universities and Campus Ministry), 24 November. Available online: http://news. ifeng.com/a/20151124/46375631_0.shtml (accessed on 17 May 2018).

Ji, Mason. 2015. Science and Technology in Modern China: A Historical and Strategic Perspective on State Power. The Yale Review of International Studies. Available online: http://yris.yira.org/essays/1551 (accessed on 2 May 2018).

Johnson, Daniel Carson. 1997. Formal Education vs. Religious Belief: Soliciting New Evidence with Multinomial Logit Modeling. Journal for the Scientific Study of Religion 36: 231-46. [CrossRef]

Johnson, Ian. 2017a. The Souls of China: The Return of Religion after Mao. New York: Knopf Doubleday.

Johnson, Ian. 2017b. Is a Buddhist Group Changing China? Or Is China Changing It? The New York Times, June 24. Available online: https:/ / www.nytimes.com/2017/06/24/world/asia/china-buddhism-fo-guang-shan. html (accessed on 17 May 2018).

Johnson, Ian. 2018. What a Buddhist Monk Taught Xi Jinping. The New York Times. January 20. Available online: https:/ / www.nytimes.com/2017/03/24/opinion/sunday/chinas-communists-embrace-religion. html (accessed on 17 May 2018).

Laliberté, André. 2011. Religion and the State in China: The Limits of Institutionalization. Journal of Current Chinese Affairs 40: 3-15.

Lehman, Edward C., and Donald W. Shriver. 1968. Academic Discipline as Predictive of Faculty Religiosity. Social Forces 47: 171-82. [CrossRef]

Mayrl, Damon, and Jeremy E. Uecker. 2011. Higher Education and Religious Liberalization among Young Adults. Social Forces 90: 181-208. [CrossRef] [PubMed] 
McFarland, Michael J., Bradley R. E. Wright, and David L. Weakliem. 2011. Educational Attainment and Religiosity: Exploring Variations by Religious Tradition. Sociology of Religion 72: 166-88. [CrossRef]

McMorrow, R. W. 2015. Membership in the Communist Party of China: Who Is Being Admitted and How? JSTOR Daily. December 19. Available online: https://daily.jstor.org/communist-party-of-china/ (accessed on 17 May 2018).

O’Brien, Timothy L., and Shiri Noy. 2015. Traditional, Modern, and Post-Secular Perspectives on Science and Religion in the United States. American Sociological Review 80: 92-115. [CrossRef]

People's Daily. 2014. Yisilanjiao Bu Zhuzhang Baoli Kongbu (Islam Is Not Equal to Violent Terriorism). People's Daily. November 8. Available online: http:/ / opinion.people.com.cn/n/2014/0811/c1003-25438524.html (accessed on 2 May 2018).

People's Daily. 2016. Ruhe Renshi He Kandai Xinjiang Zongjiao Yu Jiduan Zhuyi (How to View Religion and Extremism in Xinjiang). People's Daily. June 3. Available online: http:/ / opinion.people.com.cn/n1/2016/ 0603/c1003-28408089.html (accessed on 2 May 2018).

Reimer, Sam. 2010. Higher Education and Theological Liberalism: Revisiting the Old Issue. Sociology of Religion 71: 393-408. [CrossRef]

Ruiter, Stijn, and Frank van Tubergen. 2009. Religious Attendance in Cross-National Perspective: A Multilevel Analysis of 60 Countries. American Journal of Sociology 115: 863-95. [CrossRef]

Sacerdote, Bruce, and Edward L. Glaeser. 2001. Education and Religion. Working Paper 8080. Cambridge, MA, USA: National Bureau of Economic Research.

Scheitle, Christopher P. 2011. U.S. College Students' Perception of Religion and Science: Conflict, Collaboration, or Independence? A Research Note. Journal for the Scientific Study of Religion 50: 175-86. [CrossRef]

Schwadel, Philip. 2011. The Effects of Education on Americans' Religious Practices, Beliefs, and Affiliations. Review of Religious Research 53: 161-82. [CrossRef]

Schwadel, Philip. 2015. Explaining Cross-National Variation in the Effect of Higher Education on Religiosity. Journal for the Scientific Study of Religion 54: 402-18. [CrossRef]

Stark, Rodney, and Roger Finke. 2000. Acts of Faith: Explaining the Human Side of Religion. Berkeley: University of California Press.

Uecker, Jeremy E., Mark D. Regnerus, and Margaret L. Vaaler. 2007. Losing My Religion: The Social Sources of Religious Decline in Early Adulthood. Social Forces 85: 1667-92. [CrossRef]

Vala, Carsten T. 2012. Protestant Christianity and Civil Society in Authoritarian China. The Impact of Official Churches and Unregistered "Urban Churches" on Civil Society Development in China in the 2000s. China Perspectives 2012: 43-52.

Wang, Xiuhua, and Jeremy E. Uecker. 2017. Education, Religious Commitment, and Religious Tolerance in Contemporary China. Review of Religious Research 59: 157-82. [CrossRef]

Weber, Max. 1993. The Sociology of Religion. Boston: Beacon Press. First published 1922.

Xie, Ying, Yunping Tong, and Fenggang Yang. 2017. Does Ideological Education in China Suppress Trust in Religion and Foster Trust in Government. Religions 8: 94. [CrossRef]

Xinhuanet. 2017. Guanche Luoshi Zhongyang Guanyu Zongjiao Gongzuo Zhongda Juece Bushu Jingyan Jiaoliuhui Zhaokai (A Conference on the Implementation of the Party's Decision on Religious Works). Xinhuanet. September 11. Available online: http:/ /www.xinhuanet.com/politics/2017-09/11/c_1121645261. htm (accessed on 17 May 2018).

Yang, Fenggang. 2006. The Red, Black, and Grey Markets of Religion in China. Sociological Quarterly 47: 93-122. [CrossRef]

Yang, Fenggang. 2015. The Other Chinese Miracle. Association of Religion Data Archives. December 1. Available online: http:/ / globalplus.thearda.com/globalplus-religion-in-china/ (accessed on 2 May 2018).

(C) 2018 by the authors. Licensee MDPI, Basel, Switzerland. This article is an open access article distributed under the terms and conditions of the Creative Commons Attribution (CC BY) license (http://creativecommons.org/licenses/by/4.0/). 